\title{
UPAYA PENANGGULANGAN TINDAK PIDANA PERJUDIAN OLEH KEPOLISIAN (Studi Kasus Polres Bukittinggi dan Polres Payakumbuh)*
}

\author{
${ }^{*}$ Failin ${ }^{1}$, Ana Ramadhona ${ }^{2}$ \\ Sekolah Tinggi Ilmu Hukum Putri Maharaja Payakumbuh \\ Canduang Koto Laweh Kecamatan Canduang Kabupaten Agam Sumatera Barat ${ }^{1}$ \\ "e-mail: failin.alin87@gmail.com \\ Jl. By Pass No. 6 Kel. Pulai Anak Air Kec. Mandiangin Koto Selayan Bukittinggi ${ }^{2}$ \\ e-mail: ana.ramadhona84@gmail.com
}

\begin{abstract}
If the crime of gambling is left in the City of Bukittinggi and the City of Payakumbuh, then it is not impossible that this future will be bleak because of the mentality of the Indonesian people, especially the younger generation will be dilapidated, even all their behavior will tend to commit crime. The formulation of the problem in this study is whether the causes of gambling crime in the jurisdiction of Bukittinggi District Police and Payakumbuh City Police ?, Are the obstacles in countering the crime of gambling by the Bukittinggi Police investigator and Payakumbuh Police investigator? and the Payakumbuh Police investigator?, the method used in this research is empirical juridical. The results showed that the causes of gambling crime in the Legal Area of Bukittinggi City Police and Payakumbuh were not only those who belonged to the "haves" group, but from the people who lacked economic conditions, lack of public understanding of religious teachings, and environmental conditions. get used to or at least invite the public to do gambling. Secondly, the obstacles encountered in countering gambling crime by the Bukittinggi City Police investigator and Payakumbuh City are limited by law enforcement officers, especially investigators, lack of facilities and infrastructure in operational costs, non-permanent gambling, some people do not want to be witnesses, lack of awareness the community and the involvement of police officers who became back-up gambling. Third, efforts to tackle the crime of gambling by the Bukittinggi City Police investigator and Payakumbuh City are carried out in a preventive and repressive manner.
\end{abstract}

Keywords: Countermeasures, Crimes, Gambling

\begin{abstract}
Abstrak
Apabila tindak pidana perjudian dibiarkan di Kota Bukittinggi dan Kota Payakumbuh, maka bukan tidak mungkin masa depan ini akan suram karena mental-mental bangsa Indonesia, apalagi generasi mudanya akan bobrok, bahkan segala perilakunya akan cendrung melakukan kriminal. Rumusan masalah dalam penelitian ini adalah Apakah penyebab terjadinya tindak pidana perjudian di wilayah hukum Polres Bukittinggi dan Polres Kota Payakumbuh?, Apakah kendala dalam penanggulangan tindak pidana perjudian oleh penyidik Polres Bukittinggi dan penyidik Polres Payakumbuh?, Bagaimanakah upaya penanggulangan tindak pidana perjudian oleh penyidik Polres Bukittinggi dan penyidik Polres Payakumbuh?, metode yang digunakan dalam penelitian ini adalah yuridis empiris. Hasil penelitian menunjukkan bahwa penyebab terjadinya tindak pidana perjudian di wilayah Hukum Polres Kota Bukittinggi dan Payakumbuh bukan hanya mereka yang termasuk dalam golongan "the haves", akan tetapi dari rakyat yang kondisi perekonomian yang kurang, kurangnya pemahaman masyarakat terhadap ajaran agama, dan kondisi lingkungan yang membiasakan atau setidaknya mengajak masyarakat untuk melakukan judi. Kedua, kendala yang ditemui dalam penanggulangan tindak pidana perjudian oleh penyidik Polres Kota Bukittinggi dan Kota Payakumbuh yaitu, terbatasnya aparat penegak hukum khususnya penyidik, minimnya sarana dan prasarana dalam biaya operasional, perjudian bersifat tidak menetap, sebahagian masyarakat tidak mau dijadikan saksi, masih kurangnya kesadaran masyarakat dan adanya keterlibatan oknum
\end{abstract}

\footnotetext{
* Naskah diterima: 28 Agustus 2018, direvisi: 09 September 2018, disetujui untuk terbit: 23 September 2018
} 
Failin dan Ana Ramadhona:Upaya Penanggulangan Tindak Pidana Perjudian...

kepolisian yang menjadi back-up perjudian. Ketiga, upaya penanggulangan tindak pidana perjudian oleh penyidik Polres Kota Bukittinggi dan Kota Payakumbuh dilakukan secara preventif dan secara represif.

Kata kunci: Penanggulangan, Tindak Pidana, Perjudian

\section{PENDAHULUAN}

Kejahatan atau tindak kriminal merupakan salah satu bentuk dari "perilaku menyimpang" yang selalu ada dan melekat pada setiap masyarakat, tidak ada masyarakat yang sepi dari kejahatan. Menurut Aparinah Saldi, perilaku menyimpang itu merupakan suatu ancaman yang nyata atau ancaman terhadap norma-norma sosial yang mendasari kehidupan atau keteraturan sosial dapat menimbulkan ketegangan individual maupun keteganganketegangan sosial dan merupakan ancaman ril atau potensil bagi berlangsungnya ketertiban sosial. (Muladi: 1984). Oleh karena itu perlu kiranya peran penegak hukum.

Dilihat dari pengertian penegak hukum itu sangat luas sekali mencakup mereka yang secara langsung maupun tidak langsung berkecimpung dalam bidang penegakan hukum. Dalam hal ini akan dibatasi pada kalangan yang langsung berkecimpung dalam bidang penegakan hukum dan tidak hanya mencakup penegakan hukum "law enforcement" akan tetapi juga mencakup tentang kedamaian terhadap hukum "peace maintenance". Kiranya sudah dapat diduga bahwa kalangan tersebut mencakup mereka yang bertugas di bidang-bidang kehakiman, kejaksaan, kepengacaraan dan kepolisian. (Soerjono Soekanto : 1983).
Polisi adalah selaku penegak hukum yang mana fungsi dari polisi tersebut diatur dalam Undang-Undang Nomor 2 tahun 2002 tentang Undang-Undang Kepolisian pada Pasal 14 ayat (1) huruf g bahwa polisi berwenang melakukan penyidikan terhadap semua tindak pidana. Pasal ini memberikan penegasan bahwa kedudukan polisi sebagai penyidik dalam tindak pidana memberikan semangat dalam kepastian hukum dalam era supremasi hukum.

Penyidik dalam Pasal 1 KUHAP (Kitab Undang-Undang Hukum Acara Pidana) adalah Pejabat Polisi Negara Republik Indonesia atau Pejabat Pegawai Negeri Sipil tertentu yang diberi wewenang khusus oleh undang-undang untuk melakukan penyidikan. Dalam hal ini berguna untuk menanggulangi suatu tindak pidana.

Untuk menanggulangi maraknya tindak pidana perjudian di Kota Bukittinggi dan Kota Payakumbuh dapat di atur dalam Pasal 303 KUHP (Kitab Undang-Undang Hukum Pidana) yang menjelaskan tentang perjudian, perbuatan oleh siapa dan apa sanksinya. Dengan unsur-unsur perbuatan itu oleh siapa, dengan tidak berhak, yang mata pencahariannya, mengadakan dan memberikan kesempatan untuk main judi, atau ikut serta dalam permainan judi diancam pidana maksimal 10 tahun atau 
pidana denda maksimal 25.000.000, (dua puluh juta rupiah).

Kejahatan tentang perjudian terjadi karena ada faktor-faktor ketidak harmonisan yang cenderung nampak begitu masyarakat terdorong ke dalam dunia modern, ialah: (Mulyana W. Kusumah : 1981)

a. Ketidak seimbangan antara konsentrasi dan kekuatan-kekuatan ekonomi pada wilayah perkotaan dengan keterbelakangan populasi pedesaan.

b. Ketidak seimbangan antara pertumbuhan penduduk dengan kemampuan ekonomi untuk menciptakan lapangan kerja.

c. Ketidak seimbangan antara tuntutantuntutan bawaan sistem ekonomi dengan perkembangan keterampilanketerampilan.

d. Dalam wilayah-wilayah perkotaan, terjadi pengurangan peranan keluarga dan orang-orang yang lebih tua sebagai alat sosialisasi utama dari lembaga dan tidak mempunyai pengendalian sosial cukup, ini digantikan oleh pranata-pranata lain, akibatnya ialah pola-pola perilaku remaja berbeda secara radikal dengan harapan-harapan keluarga.

e. Perubahan-perubahan dalam nilainilai yang menolak penerimaan fatalistik atas kondisi-kondisi kemiskinan, dalam kondisi mana secara tradisionil, masyarakat hidup.

Jika perbuatan tindak pidana perjudian dari hari-kehari dibiarkan di Kota Bukittinggi dan Kota Payakumbuh, maka bukan tidak mungkin masa depan ini akan suram karena mental-mental bangsa Indonesia, apalagi generasi mudanya akan bobrok, bahkan segala perilakunya akan cendrung melakukan kriminal. Tindak pidana perjudian di Wilayah Hukum Polres Bukittingi cukup tinggi dari kota lain, hal ini dapat dilihat dari persentase kasus yang ada sejak tahun 2010 sampai 2016 mencapai 74 kasus yang terjadi di Polres Bukittinggi. Dan Tindak pidana perjudian di Wilayah Hukum Polres Payakumbuh juga cukup tinggi dari kota lain, hal ini dapat dilihat dari persentase kasus yang ada sejak tahun 2010 sampai 2016 mencapai 70 kasus yang terjadi di Polres Payakumbuh. Untuk itu perlu dilakukan pencegahan dan penanggulangan secara dini, misalnya melakukan razia-razia secara intensif, dan melakukan upaya-upaya lainnya sehingga bentuk-bentuk perjudian dapat diminimalisir atau dikikis habis.

\section{METODE PENELITIAN}

Dalam penelitian ini penulis menggunakan metode pendekatan yuridis empiris yaitu pendekatan terhadap permasalahan penelitian dari aspek yuridis dan praktik hukum di lapangan tentang upaya penanggulangan tindak pidana perjudian oleh Polres Bukittinggi dan Polres Payakumbuh.

Bahwa penelitian ini bersifat Deskriptif, yaitu penelitian yang memberikan data tentang sesuatu atau gejala-gejala sosial yang berkembang di tengah-tengah masyarakat sehingga dengan adanya penelitian ini diharapkan dapat memperoleh gambaran yang 
Failin dan Ana Ramadhona:Upaya Penanggulangan Tindak Pidana Perjudian...

menyeluruh, lengkap dan sistematis tentang objek yang akan di teliti.

Setelah semua data berhasil dikumpulkan berdasarkan penelitian yang dilakukan di lapangan, maka data tersebut disatukan untuk kelanjutan diolah sedemikian rupa secara sistematik. Dari pengolahan data yang telah dilakukan, selanjutnya perlu dilakukan analisa sehingga menghasilkan data dalam bentuk uraian kalimat yang kritis dan relevan dengan pemecahan permasalahan. Untuk itu digunakan analisa kualitatif, yaitu hasil penelitian kepustakaan akan dipergunakan untuk menganalisa data yang diperoleh dari lapangan dan kemudian data primer dan data sekunder dianalisa secara kualitatif untuk menjawab permasalahan dalam penelitian ini.

\section{HASIL DAN PEMBAHASAN}

\section{Penyebab Terjadinya Tindak Pidana Perjudian Di Wilayah Hukum Polres Bukittinggi dan Polres Payakumbuh}

Perjudian merupakan salah satu sisi gelap budaya Kota Bukittinggi dan Kota Payakumbuh yaitu dalam hal tingkat kriminalitasnya yang tinggi. Dari hasil penelitian yang telah penulis lakukan bahwa jenis perjudian yang dilakukan di Kota Bukittinggi dan Kota Payakumbuh adalah jenis Togel, Domino, Ceki (Koa), Remi.

Perjudian di Kota Bukittinggi dan Payakumbuh merupakan suatu hal yang biasa atau lumrah dilakukan. Hampir di setiap sudut kota, baik siang maupun malam kita bisa menjumpai masyarakat baik kalangan atas maupun kalangan bawah yang melakukan perjudian.

Tabel: Statistik tindak pidana perjudian di Polres Kota Bukittinggi dari tahun 2010 s/d tahun 2016 berdasarkan jenis perjudian yang dilakukan.

\begin{tabular}{cccccc}
\hline \multirow{2}{*}{ Tahun } & Jumlah & \multicolumn{5}{c}{ Jenis Perjudian } \\
& & T & D & C & R \\
\hline 2010 & 3 & 2 & - & - & 1 \\
2011 & 5 & 2 & 1 & 1 & 1 \\
2012 & 7 & 3 & 1 & 1 & 2 \\
2013 & 10 & 5 & 1 & - & 4 \\
2014 & 15 & 4 & 2 & 4 & 5 \\
2015 & 17 & 8 & 2 & 2 & 5 \\
2016 & 17 & 10 & 2 & - & 5
\end{tabular}

Jumlah

74 Kasus

Ket: $\mathrm{T}$ (togel), $\mathrm{D}$ (domino), $\mathrm{C}=$ (ceki/koa), $\mathrm{R}$ (remi)

Sumber data Polres Kota Bukittinggi

Tabel: Statistik tindak pidana perjudian di Polres Kota Payakumbuh dari tahun 2010 s/d tahun 2016 berdasarkan jenis perjudian yang dilakukan.

\begin{tabular}{cccccc}
\hline & & \multicolumn{5}{c}{ Jenis Perjudian } \\
Tahun & Jumlah & T & D & C & R \\
\hline 2010 & 5 & 5 & - & - & - \\
2011 & 16 & 5 & 3 & 3 & 5 \\
2012 & 5 & 2 & 2 & - & 1 \\
2013 & 7 & 4 & - & 2 & 1 \\
2014 & 10 & 5 & 2 & 2 & 1 \\
2015 & 13 & 7 & 3 & 1 & 2 \\
2016 & 14 & 10 & 1 & 1 & 2 \\
Jumlah & & 70 Kasus & & \\
\hline
\end{tabular}

Ket: $\mathrm{T}$ (togel), D (domino), $\mathrm{C}=$ (ceki/koa), $\mathrm{R}$ (remi).

Sumber data Polres Kota Payakumbuh 
Tabel tersebut diatas menunjukkan bahwa jenis perjudian Togel secara umum masih dominan jika dibandingkan dengan jenis perjudian lainnya yang dilakukan oleh masyarakat Kota Bukittinggi dan Payakumbuh. Pelaku tindak pidana perjudian melakukan ditempat umum dan permainan judi tidak ada larangan dari masyarakat sekitarnya dan malah membudaya di tengah kehidupan seharihari baik orang tua maupun anak yang dibawah umur.

Hasil wawancara dari Bapak Sulaiman Pane Kanit II Reskrim Polres Bukittinggi menyatakan:

1. Bahwa maraknya perjudian disebabkan oleh kondisi perekonomian yang kurang;

2. Kurangnya pemahaman masyarakat terhadap ajaran agama;

3. Kondisi lingkungan yang membiasakan atau setidaknya mengajak masyarakat untuk melakukan.

Hasil wawancara dari Bapak Doni Pramadona Kanit Reskrim Polres Payakumbuh menyatakan:

1. Perjudian dilakukan bukan karena faktor ekonomi tapi karena faktor ikut-ikutan;

2. Kurangnya pemahaman masyarakat terhadap ajaran agama;

3. Kondisi lingkungan yang mengajak masyarakat untuk melakukan judi.

Dari hasil wawancara penulis di Polres Bukittinggi dan Payakumbuh terlihat bahwa kebanyakan pemain judi bukan hanya mereka yang termasuk dalam golongan "the haves", akan tetapi terdiri dari rakyat miskin, pegawaipegawai, pekerja atau buruh yang bergaji kecil, pedagang-pedagang, tukang becak, sopir, dan kuli-kuli yang berpenghasilan rendah. Penghasilan yang sangat rendah, dan dapat dianggap tidak mencukupi untuk memenuhi kebutuhan hidup anggota keluarga seringkali membuat orang mengambil jalan pintas tanpa usaha keras untuk memperoleh keuntungan dengan cara berjudi.

Telah dijelaskan bahwa segala bentuk perjudian yang didasarkan pengharapan buat menang pada umumnya tergantung pada untung-untungan saja dan juga kalau pengharapan itu jadi bertambah besar karena kepintaran dan kebiasaan pemain (Pasal 303 KUHP). Jadi dalam hal ini jelas permainan judi tersebut ada taruhan oleh pihak-pihak tertentu.

Berdasarkan hasil penelitian di Polres Bukittinggi dan Polres Payakumbuh bahwa segala bentuk perjudian yang mana perbuatan tersebut yang dilarang oleh peraturan perundang-undangan baik oleh peraturan perundang-undangan hukum nasional maupun hukum agama. Dengan dasar inilah suluruh jajaran Polres Bukittinggi dan Polres Payakumbuh melakukan upaya-upaya penanggulangan, pencegahan tindak pidana perjudian. Sebab perjudian dilarang dan pelakunya diproses sesuai dengan hukum yang berlaku, akan tetapi permainan judi ini tetap sering terjadi di tengah-tengah masyarakat baik itu yang dilakukan secara tersembunyi maupun secara terangterangan, dengan berdalih untuk hiburan. 
Failin dan Ana Ramadhona:Upaya Penanggulangan Tindak Pidana Perjudian...

Namun ada pula yang melakukan permainan secara iseng saja untuk menghabiskan waktu belaka atau hanya sekedar untuk relax dan kesempatan demi kesempatan telah membinanya menjadi kebiasaan.

Ralph R. Greenson dikemukakan oleh Reckless sebagai penulis yang membedakan type penjudi dan terdiri atas:

1. Manusia normal, ialah mereka yang melakukan perjudian sebagai selingan atau hiburan dan mampu untuk menghentikan pada saat ia menghendakinya;

2. Penjudi professional memilih jalan hidupnya sebagai penjudi;

3. Penjudi neorotis, ialah mereka yang melakukan perjudian karena didorong oleh kebutuhan yang tidak didasari dan oleh karena itu menghadapi kesulitan untuk menghentikan kebiasaan bermain judi.

Berdasarkan wawancara dengan salah seorang pelaku dari tindak pidana perjudian di Kota Payakumbuh yaitu Bapak Mardion. St. Marajo, yang menyatakan: "Bahwa dirinya melakukan permainan judi sebagai selingan untuk menghabiskan waktu luang, karena sering melakukan permainan judi lama kelamaan jadi kebiasaan dan dilakukan sebagai ajang taruhan kemudian mendapat kesulitan untuk menghentikan kebiasaan berjudi tersebut".

Berdasarkan hasil penelitian penulis pada Polres Kota Payakumbuh, jenis perjudian yang sering terjadi di tengah- tengah masyarakat Kota Bukittinggi adalah Togel, Domino, Ceki (Koa), Remi. Hal ini dibenarkan oleh Bapak Sulaiman Pane, yang menyatakan: "Bentuk judi yang sering kami temukan atau tangkap di Bukittinggi adalah Togel, Domino, Ceki (Koa), Remi dengan dalih untuk mengisi waktu luang padahal setelah digeledah perjudian ditemukan bukti-bukti kuat bahwa pihak-pihak melakukan itu pertaruhan berupa uang dalam permainan itu".

Wawancara dengan salah seorang pelaku dari tindak pidana perjudian yaitu Bapak Amir di Kota Payakumbuh, yang menyatakan: "Bahwa dirinya melakukan tindak pidana perjudian untuk mencari tambahan kebutuhan hidup yang merupakan mata pencarian sehingga mencoba untuk mengadu nasib melalui permainan judi yaitu togel, permainan judi yang hasilnya selama ini membantu memenuhi kehidupannya sehari-hari untuk mendapatkan keuntungan tanpa adanya usaha yang sifatnya menunggu (tanpa bekerja keras)".

Sebab cara pelaksanaan permainan judi tersebut mudah sekali dan tidak mengenal waktu serta tempat, dengan demikian perjudian ini dapat dilakukan secara gampang dan mudah. Sehingga perjudian berkembang biak secara pelaksanaannya maupun bentuknya, hal ini bisa terjadi di kota-kota maupun di desa-desa. Bahkan boleh dikatakan bahwa perjudian telah menjalar dan menjamur di tengah-tengah kehidupan masyarakat. Para pelaku tindak pidana perjudian yang sudah diproses pada umumnya mengaku 
bahwa dirinya menyesal telah melakukan perbuatan tindak pidana perjudian dan malu terhadap keluarga serta malu kepada sang Maha Pencipta.

\section{Kendala-Kendala Dalam}

Penanggulangan Tindak Pidana

Perjudian Oleh Penyidik Polres

Bukittinggi dan Penyidik Polres

Payakumbuh

Berdasarkan hasil wawancara dengan Bapak Sulaiman Pane yang menyatakan: ada beberapa hal kendala-kendala atau hambatan yang dialami pihak Polres Kota Bukittinggi dalam penanggulangan perjudian, hambatan yang berasal dari masyarakat / pihak kepolisian, yaitu:

a. Terbatasnya aparat penegak hukum khususnya penyidik petugas yang ada di Polres Kota Bukittinggi yang merupakan suatu hambatan dalam penanggulangan tindak pidana perjudian

b. Minimya sarana dan prasarana dalam biaya operasional untuk melakukan penanggulangan tindak pidana perjudian, jika dibandingkan perkembangan kejahatan secara umum yang cendrung selalu berkembang baik kuantitasnya maupun modus operandinya yang sulit dideteksi secara dini karena modusnya mengikuti perkembangan IPTEK.

c. Perjudian bersifat tidak menetap atau berpindah-pindah tempat dalam melakukan perjudian.

d. Sebahagian masyarakat tidak mau dijadikan saksi dalam perkara tindak pidana perjudian. e. Masih kurangnya kesadaran masyarakat untuk melaporkan tindak pidana perjudian yang merugikan kepada masyarakat maupun pelaku sendiri.

f. Adanya oknum kepolisian yang menjadi back-up perjudian.

Sedangkan Berdasarkan hasil wawancara dengan Bapak Doni Pramadona yang menyatakan: ada beberapa hal kendala-kendala atau hambatan yang dialami pihak Polres Kota Payakumbuh dalam penanggulangan perjudian, hambatan yang berasal dari masyarakat / pihak kepolisian, yaitu:

1. Kurangnya Anggaran untuk penanganan tindak pidana perjudian.

2. Kurang penguasaan teknologi informasi oleh penyidik dalam mengungkap pelaku perjudian.

3. Kurangnya jumlah personil dalam melakukan penanganan tindak pidana perjudian

4. Terbatasnya sarana dan prasarana

Soerjono Soekanto menggunakan tolak ukur efektivitas dalam penegakan hukum pada lima hal yakni :

1. Faktor Hukum

Hukum berfungsi untuk keadilan, kepastian dan kemanfaatan. Dalam praktik penyelenggaraan hukum di lapangan ada kalanya terjadi pertentangan antara kepastian hukum dan keadilan. Kepastian Hukum. sifatnya konkret berwujud nyata, sedangkan keadilan bersifat abstrak sehingga ketika seseorang hakim memutuskan suatu perkara secara penerapan undang-undang saja maka ada 
Failin dan Ana Ramadhona:Upaya Penanggulangan Tindak Pidana Perjudian...

kalanya nilai keadilan itu tidak tercapai. Maka ketika melihat suatu permasalahan mengenai hukum setidaknya keadilan menjadi prioritas utama. Karena hukum tidaklah semata-mata dilihat dari sudut hukum tertulis saja.

2. Faktor Penegakan Hukum

Dalam berfungsinya hukum, mentalitas atau kepribadian petugas penegak hukum memainkan peranan penting, kalau peraturan sudah baik, tetapi kualitas petugas kurang baik, ada masalah. Selama ini ada kecenderungan yang kuat di kalangan masyarakat untuk mengartikan hukum sebagai petugas atau penegak hukum, artinya hukum diidentikkan dengan tingkah laku nyata petugas atau penegak hukum. Sayangnya dalam melaksanakan wewenangnya sering timbul persoalan karena sikap atau perlakuan yang dipandang melampaui wewenang atau perbuatan lainnya yang dianggap melunturkan citra dan wibawa penegak hukum. Hal ini disebabkan oleh kualitas yang rendah dari aparat penegak hukum tersebut.

\section{Faktor Sarana atau Fasilitas Pendukung}

Faktor sarana atau fasilitas pendukung mencakup perangkat lunak dan perangkat keras, Menurut Soerjono Soekanto bahwa para penegak hukum tidak dapat bekerja dengan baik, apabila tidak dilengkapi dengan kendaraan dan alat-alat komunikasi yang proporsional. Oleh karena itu, sarana atau fasilitas mempunyai peranan yang sangat penting di dalam penegakan hukum. Tanpa adanya sarana atau fasilitas tersebut, tidak akan mungkin penegak hukum menyerasikan peranan yang seharusnya dengan peranan yang aktual.

4. Faktor Masyarakat

Penegak hukum berasal dari masyarakat dan bertujuan untuk mencapai kedamaian di dalam masyarakat. Setiap warga masyarakat atau kelompok sedikit banyaknya mempunyai kesadaran hukum. Persoalan yang timbul adalah taraf kepatuhan hukum, yaitu kepatuhan hukum yang tinggi, sedang, atau kurang. Adanya derajat kepatuhan hukum masyarakat terhadap hukum, merupakan salah satu indikator berfungsinya hukum yang bersangkutan.

5. Faktor Kebudayaan

Kebudayaan pada dasarnya mencakup nilai-nilai yang mendasari hukum yang berlaku, nilai-nilai mana yang merupakan konsepsi-konsepsi yang abstrak mengenai apa yang dianggap baik (sehingga dituruti) dan apa yang dianggap buruk (sehinga dihindari). Maka, kebudayaan Indonesia merupakan dasar atau mendasari hukum adat yang berlaku. Di samping itu berlaku pula hukum tertulis (perundang-undangan), yang dibentuk oleh golongan tertentu dalam masyarakat yang mempunyai kekuasaan dan wewenang untuk itu. Hukum perundang-undangan tersebut harus dapat mencerminkan nilai-nilai yang menjadi dasar dari hukum adat, agar hukum perundang-undangan tersebut dapat berlaku secara aktif. (Soerjono Soekanto: 2007). 
Sebagian masyarakat masih memandang bahwa perjudian adalah warisan nenek moyangnya dan bukan merupakan pelanggaran hukum, perjudian dianggap sebagai budaya. Agak sulit mengatakan bahwa ada ideologi tertentu dibalik perjudian karena di dalam berbagai ideologi tanpa harus diperkenalkan oleh ideologi yang berasal dari luar masyarakatnya, perjudian merupakan mekanisme naluriah yang seakan telah ada bersama-sama dengan keberadaan suatu komunitas.

\section{Upaya Penanggulangan Tindak Pidana Perjudian Oleh Penyidik Polres Bukittinggi dan Penyidik Polres Payakumbuh}

Pemerintahan Kota Bukittinggi dan Payakumbuh telah melakukan langkahlangkah untuk memberantas, menanggulangi atau membasmi tindak pidana perjudian. Langkah-langkah penanggulangan ini perlu diperkirakan secara objektif sehingga berjalan secara efektif tanpa mengabaikan norma-norma, khususnya norma kesopanan yang terdapat di tengah- tengah masyarakat. Dengan kata lain perlu adanya suatu pengamatan yang tajam dan mendalam tentang sruktur masyarakat, dipensi yang melatar belakangi perjudian atas kekuatan makro sosiologis, supaya kita terlepas dari cengkraman stuktur kehidupn yang suram dan merugikan masyarakat, bangsa dan negara.

Berdasarkan hasil wawancara dengan Bapak Syafri, Kanit Reskrim Polres Bukittinggi yang mengatakan: "Bahwa tindak pidana perjudian di Wilayah
Hukum Bukittinggi boleh dikatakan tidak meresahkan lagi bagi warga masyarakat Bukittinggi, karena sudah mulai berkurang dari tahun ke tahun dengan telah mengadakan penyuluhan, baik mengundang tokoh-tokoh masyarakat, sekolah, maupun membuat spanduk dan melakukan razia secara intensif dan lain sebagainya".

Berdasarkan Pasal 13 Undangundang Nomor 2 tahun 2002 tentang Kepolisian Negara Republik Indonesia menyebutkan bahwa tugas pokok kepolisian Negara Republik Indonesia adalah:

1. Memelihara keamanan dan ketertiban masyarakat.

2. Menegakkan hukun dan memberikan perlindungan, pengayoman, dan pelayanan kepada masyarakat.

Ada dua teori penanggulangan yang telah dilakukan termasuk kejahatan perjudian ini khususnya, yaitu pola Preventif (dilakukan pencegahan sebelum terjadinya kejahatan) dan pola Represif (pencegahan setelah terjadinya kejahatan, kejahatan ini biasanya disebut proses secara hukum).

Di Wilayah Hukum Polres Bukitinggi berdasarkan wawancara dengan Kanit II Reskrim Polres Kota Bukittinggi pencegahan dan penanggulangan secara Preventif tindak pidana perjudian maka pihak Polres Kota Bukittinggi mengupayakan melalui:

1. Menghimbau warga masyarakat melalui pejabat daerah tersebut (Kecamatan dan kelurahan) dalam 
Failin dan Ana Ramadhona:Upaya Penanggulangan Tindak Pidana Perjudian...

berbagai kesempatan pertemuan untuk tetap waspada terhadap kemungkinan-kemungkinan terjadinya gangguan dari orang-orang yang bertanggung jawab.

2. Membuat program penyuluhan hukum kepada organisasi-organisasi kepemudaan seperti Karang Taruna, sekolah-sekolah, dengan melibatkan berbagai unsur masyarkat, yaitu pemuka adat, pemuka agama yang dilakukan setiap kecamatan dan kelurahan.

3. Memperdayakan lembaga-lembaga sosial lainnya untuk ikut mekampanyekan gerakan anti kejahatan seperti gerakan anti narkoba, anti miras dan judi di setiap kecamatan dan kelurahan.

Sedangkan tindakan secara represif tindak pidana perjudian dalam rangka pencegahan dan penanggulangan tindak kejahatan bedasarkan hasil wawancara dengan Kanit II Reskrim Polres Kota Payakumbuh menyatakan: setiap tindakan preventif harus diikuti dengan tindakan represif. Tindakan represif yang dilakukan untuk mencegah tindak pidana perjudian adalah:

1. Dilakukan razia secara intensif. Hal ini dilakukan terlebih dahulu daerahdaerah yang sebelumnya telah dicurigai sebagai daerah yang berpotensi melakukan tindak pidana perjudian, lokasi penjualan togel dan tempat berkumpulnya anak-anak muda.

2. Menindak lanjuti dengan cepat setiap diketahui telah terjadi tindak pidana perjudian berdasarkan adanya laporan dari masyarakat ataupun pengaduan apalagi diketahui langsung oleh pihak kepolisian.

3. Apabila tindak pidana perjudian dilakukan oleh anak dibawah umur atau anak yang masih sekolah, memanggil orang tuanya atau gurunya untuk diajak secara bersamasama mencegah terjadinya tindak pidana yang dilakukan oleh si anak atau si murid.

\section{SIMPULAN}

Kesimpulan penelitian ini sebagai berikut: pertama, Penyebab terjadinya tindak pidana perjudian di wilayah Hukum Polres Kota Bukittinggi dan Payakumbuh bukan hanya mereka yang termasuk dalam golongan "the haves", akan tetapi dari rakyat yang kondisi perekonomian yang kurang, kurangnya pemahaman masyarakat terhadap ajaran agama, dan kondisi lingkungan yang membiasakan atau setidaknya mengajak masyarakat untuk melakukan judi. Kedua, kendala yang ditemui dalam penanggulangan tindak pidana perjudian oleh penyidik Polres Kota Bukittinggi dan Kota Payakumbuh yaitu, terbatasnya aparat penegak hukum khususnya penyidik, minimnya sarana dan prasarana dalam biaya operasional, perjudian bersifat tidak menetap, sebahagian masyarakat tidak mau dijadikan saksi, masih kurangnya kesadaran masyarakat dan adanya keterlibatan oknum kepolisian yang menjadi back-up perjudian.

Ketiga, upaya penanggulangan tindak pidana perjudian oleh penyidik Polres 
Kota Bukittinggi dan Kota Payakumbuh dilakukan secara preventif dan secara represif. Upaya penanggulangan secara preventif dalam kesempatan tertentu melakukan penyuluhan hukum kepada masyarakat, mengampanyekan gerakan anti kejahatan seperti: gerakan anti narkoba, anti miras dan khususnya judi yang bekerja sama dengan aparat pemerintah setempat di masing-masing kecamatan dan kelurahan serta juga pemuka-pemuka masyarakat lainnya. Sedangkan secara represif selain mengoptimalkan aparat penegak hukum khususnya penyidik, juga bekerja sama dengan pemuda untuk melakukan razia dan melakukan penindakan hukum kepada pelaku yang tidak mengindahkan seruan-seruan secara preventif di atas sesuai dengan perbuatannya.

\section{SARAN}

Diharapkan terhadap masyarakat agar terciptanya masyarakat yang aman dari tindak pidana perjudian hendaknya masyarakat lebih berusaha lagi dalam memenuhi kebutuhannya dengan jalan bekerja lebih giat sehingga kebutuhannya dapat terpenuhi, maka dengan demikian perjudian tidak akan terjadi di tengahtengah masyarakat dan hendaknya masyarakat lebih sadar akan bahaya perjudian sehingga bersedia bekerja sama untuk memberikan informasi kepada aparat penegak hukum apabila terjadi perjudian.
Diharapkan kepada aparat kepolisian dalam menghadapi hambatan-hambatan tersebut agar dapat mengedepankan fungsi Bimbingan Masyarakat (Bimas) secara intensif, dan apabila ada oknum dari pihak kepolisian yang menjadi backup perjudian, agar oknum tersebut dapat ditindak sesuai dengan hukum yang berlaku.

\section{DAFTAR PUSTAKA}

Adami Chazawi, 2005, Tindak Pidana Mengenai Kesopanan, PT.Raja Gravindo Persada, Jakarta.

B.Simandjuntak, 1980, Pengantar Kriminologi dan Patologi Sosial, Transito, Bandung.

1977, Masalah

Kejahatan dengan Sebab dan

Akibat, Pradnya Paramita, Jakarta.

Mahmud Yunus, 1978, Tafsir Qur'an Karim, PT Hidakarya Agung Jakarta.

Muladi, 1984, Teori-Teori dan Kebijaka Pidana, Alumni, Bandung.

Mulyana W. Kusumah, 1981, Aneka Permasalahan Dalam Ruang Lingkup Kriminologi, Alumni, Bandung.

Soerjono Soekanto, 1983, Faktor-Faktor Yang Mempengaruhi Penegakan Hukum, Jakarta.

Soerjono Soekanto, 2007, Faktor-Faktor yang Mempengaruhi Penegakan Hukum, Penerbit PT. Raja Grafindo Persada, Jakarta.

www.google.com/ jenis-jenis perjudian.co.id. 